\title{
Realtime tuning and verification of compartmental cell models using RTXI and GENESIS
}

\author{
Hugo Cornelis ${ }^{1 *}$, Allan D Coop ${ }^{2}$ \\ From Nineteenth Annual Computational Neuroscience Meeting: CNS*2010 \\ San Antonio, TX, USA. 24-30 July 2010
}

The GEneral NEural SImulation System (GENESIS) has recently been reconfigured to resolve problems resulting from the rapidly increasing complexity of neural modeling software. Modularization of GENESIS according to the Computational Biology Initiative (CBI-[1]) functional software architecture has provided important advantages by facilitating the easy integration of new simulator functionality while maintaining an open developer community. The complexity of individual software modules is greatly reduced from that of a complete simulation system, documentation is simplified when modules are independent, they can be more easily tested, added or removed, and the scope of a new module is clearly delineated. Unlike GENESIS versions 1 and 2, the modular construction of GENESIS-3 (G-3) is designed to greatly facilitate the development of new tools to support simulation-based education, collaboration, and model publication.

The Real-Time eXperimental Interface (RTXI) is a mature modular dynamic clamp implementation growing out of previous work by Butera [2] and White [3] for hard realtime (RT) data acquisition. RTXI is modular to the extent that user-supplied function-specific code models can be combined to build custom experimental protocols and interfaces. RTXI provides an event delivery system that allows these plug-ins to signal the occurrence of user-defined events amongst themselves as required.

We report on our efforts to interface G-3 with RTXI to develop an integrated software platform. This platform will greatly increase the power of dynamic clamp technology and in return deliver RT quantification and 'tuning' of the parameters of cell and tissue models. Figure 1.

\footnotetext{
* Correspondence: coop@uthscsa.edu

'Department of Epidemiology and Biostatistics, University of Texas Health Sciences Center at San Antonio, San Antonio, TX 78229, USA
}

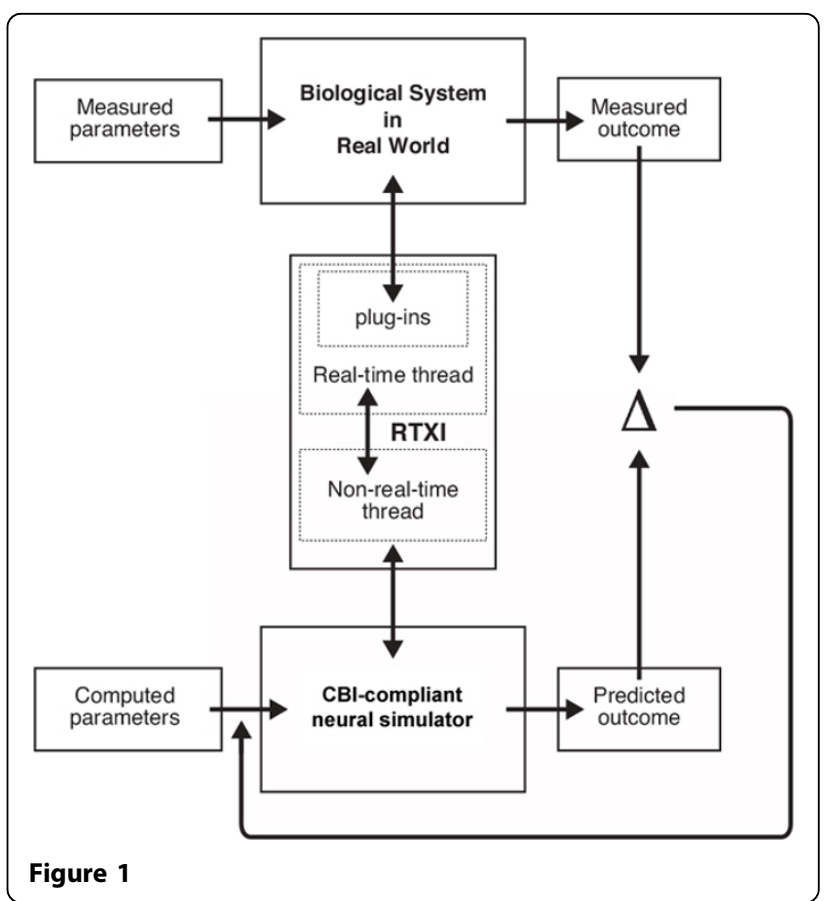

Acknowledgements

This research was supported by a NSF grant (HRD-0932339) to the University of Texas at San Antonio.

\section{Author details}

${ }^{1}$ Department of Epidemiology and Biostatistics, University of Texas Health Sciences Center at San Antonio, San Antonio, TX 78229, USA. ${ }^{2}$ Research Imaging Institute, University of Texas Health Sciences Center at San Antonio, San Antonio, TX 78229, USA.

Published: 20 July 2010

References

1. Cornelis $\mathrm{H}$, Edwards M, Coop AD, Bower JM: The CBI architecture for computational simulation of realistic neurons and circuits in the GENESIS 3 software federation. BMC Neurosci 2008, 9(S1):88. 
2. Butera RJ Jr, Wilson CG, Delnegro CA, Smith JC: A methodology for achieving high-speed rates for artificial conductance injection in electrically excitable biological cells. IEEE Trans Biomed Eng 2001, 48:1460-1470.

3. Dorval AD, Christini DJ, White T, Real-time linux dynamic clamp: A fast and flexible way to construct virtual ion channels in living cells. Ann. Biomed. Eng 2001, 29:897-907.

doi:10.1186/1471-2202-11-S1-P68

Cite this article as: Cornelis and Coop: Realtime tuning and verification of compartmental cell models using RTXI and GENESIS. BMC

Neuroscience 2010 11(Suppl 1):P68.

Submit your next manuscript to BioMed Central and take full advantage of:

- Convenient online submission

- Thorough peer review

- No space constraints or color figure charges

- Immediate publication on acceptance

- Inclusion in PubMed, CAS, Scopus and Google Scholar

- Research which is freely available for redistribution

Submit your manuscript at www.biomedcentral.com/submit
C Biomed Central 